\title{
Pengaruh Konsentrasi Larutan Prekursor Terhadap Morfologi dan Ukuran Kristal Nanopartikel Seng Oksida
}

\author{
Fitria Ardhiati*, Muldarisnur \\ Laboraturium Fisika Material, Jurusan Fisika \\ Fakultas Matematika dan Ilmu Pengetahuan Alam Universitas Andalas \\ Kampus Unand Limau Manis, Padang, 25163 Indonesia \\ *ardhiafitri96@gmail.com
}

\begin{abstract}
ABSTRAK
Pengaruh konsentrasi larutan prekursor terhadap morfologi dan ukuran nanopartikel seng oksida ( $\mathrm{ZnO})$ yang disintesis menggunakan metode hidrotermal telah diteliti. Larutan $\mathrm{ZnO}$ dengan konsentrasi $15 \mathrm{mM}$, $20 \mathrm{mM}, 25 \mathrm{mM}, 30 \mathrm{mM}$ dan $35 \mathrm{mM}$ disiapkan menggunakan prekursor zinc nitrate tetrahydrate dan hexamethylenetetramine dengan pelarut aquades. Morfologi nanopartikel $\mathrm{ZnO}$ yang terbentuk dikarakterisasi menggunakan Scanning Electron Microscope (SEM) dan ukuran kristal dikarakterisasi menggunakan XRD. Hasil karakterisasi menggunakan SEM menujukkan bahwa sampel yang tebentuk mengalami aglomerasi. Hasil karakterisasi XRD menunjukkan bahwa sampel adalah ZnO dengan struktur heksagonal Ukuran kristal dihitung menggunakan persamaan Debye-Scherrer dan diperoleh bahwa ukuran kristal berada pada rentang 25,4 - 27,5 nm. Dari penelitian diperoleh bahwa variasi konsentrasi larutan prekursor menyebabkan adanya perubahan ukuran kristal tapi tidak terlalu signifikan.

Kata kunci: Zno, hidrotermal, ukuran kristal
\end{abstract}

\begin{abstract}
Effect of concentration on precursors on the morphology and size of zinc oxide (ZnO) nanoparticles synthesized using the approved hydrothermal method. The ZnO solution with a composition of $15 \mathrm{mM}, 20$ mM, $25 \mathrm{mM}, 30 \mathrm{mM}$ and $35 \mathrm{mM}$ was prepared using precursor zinc nitrate tetrahydrate and hexamethylenetetramine with distilled water solvent. The morphology of ZnO nanoparticles formed was characterized using Scanning Electron Microscope (SEM) and the crystal size was characterized using $X R D$. The results of characterization using SEM showed that the sample formed changed agglomeration. The XRD characterization results show that the sample is $\mathrm{ZnO}$ with hexagonal structure Crystal size is calculated using the Debye-Scherrer equation and crystal size is obtained in the range of $25.4-27.5 \mathrm{~nm}$. From the results of the research obtained variations in the results of the precursors caused a change in the crystal size but not too significant.

Keywords: Zno, hydrothermal, crystal size
\end{abstract}

\section{PENDAHULUAN}

Teknologi nano berkembang sangat pesat dalam dua dekade terakhir. Teknologi nano memanfaatkan struktur berskala kecil yaitu sekitar $10^{-9}$ meter untuk mendapatkan sifat-sifat yang tidak dapat dihasilkan oleh partikel berukuran besar (bulk). Perubahan sifat nanopartikel berkaitan dengan fenomena kuantum sebagai akibat keterbatasan ruang gerak elektron dan pembawa muatan lainnya dalam partikel (Abdullah, 2009). Fenomena ini berimbas pada beberapa sifat material antara lain sifat listrik, sifat optik, dan perubahan warna luminesensi yang dipancarkan oleh nanopartikel (Witjaksono, 2011).

Salah satu material yang paling banyak dikembangkan dalam orde nano adalah semikonduktor. Semikonduktor banyak dikembangkan karena memiliki tingkat energi yang bervariasi sehingga dapat dimanfaatkan sebagai konduktor maupun isolator. Material semikonduktor dapat dimanfaatkan pada berbagai bidang diantaranya sebagai lapisan semikonduktor oksida pada solar cell. Salah satu material semikonduktor yang paling banyak dikembangkan dalam skala nano adalah seng oksida $(\mathrm{ZnO})$.

Seng oksida $(\mathrm{ZnO})$ merupakan semikonduktor yang banyak diteliti karena memiliki energi gap 3,37 eV yang bersesuaian dengan sinar ultra violet. Kelebihan lain partikel seng oksida adalah energi ikat exciton bebasnya yang besar yaitu sekitar $60 \mathrm{meV}$ sehingga memungkinkan terjadinya emisi excitonic secara efisien pada temperatur ruang (Raji dan Gopchandran, 2017). Seng oksida memiliki sifat-sifat optik, akustik, dan kelistrikan yang menarik sehingga digunakan dalam bidang elektronik, optoelektronik, sensor, dan lain-lain. 
Sebagai bahan semikonduktor dengan celah energi yang besar, seng oksida sangat potensial sebagai elektroda transparan pada sel surya (Saragi dkk., 2015).

Metode preparasi mempengaruhi sifat dari nanopartikel seng oksida yang disintesis. Oleh karena itu, metode sintesis nanopartikel harus dipilih sesuai dengan aplikasi yang diinginkan. Beberapa metode sintesis nanopartikel seng oksida antara lain adalah Chemical Vapour Deposition (CVD), sol-gel, dan Electro Chemical Deposition (ECD). Metode CVD dan ECD dapat menghasilkan nanopartikel seng oksida yang berukuran di bawah 100 nanometer dengan kemurnian yang tinggi. Metode-metode tersebut sayangnya membutuhkan preparasi pada temperatur yang tinggi atau keadaan vakum sehingga sulit diterapkan dalam skala industri karena relatif mahal (Ikono, dkk., 2012). Metode lain yang paling umum digunakan untuk mensintesis nano partikel seng oksida adalah sol-gel. Metode sol-gel umum digunakan karena relatif sederhana dan dapat menghasilkan koloid seng oksida dengan ukuran partikel sekitar tiga nanometer dalam waktu beberapa jam (Abdullah, 2009). Pada proses sol-gel nanopartikel terbentuk melalui fasa koloid tidak langsung dari fasa cair sehingga terjadi reduksi massa yang signifikan.

Metode lain untuk mensintesis nanopartikel seng oksida adalah hidrotermal. Sintesis nanopartikel menggunakan metode hidrotermal lebih baik dibandingkan dengan metode-metode konvensional (Saragi dkk., 2016). Metode hidrotermal dapat dilakukan pada temperatur yang relatif rendah yaitu pada kisaran $90{ }^{\circ} \mathrm{C}-300{ }^{\circ} \mathrm{C}$. Pada metode hidrotermal, nanopartikel langsung terbentuk dari larutan, sehingga ukuran dan morfologi partikel dapat dikontrol dengan mengatur temperatur dan konsentrasi awal prekursor.

Chitira dan John (2017) menemukan bahwa tekanan vakum dan temperatur annealing mempengaruhi luas permukaan nanopartikel seng oksida yang terbentuk sehingga dapat mempengaruhi sifat optik seng oksida. Variasi temperatur annealing saat sintesis dapat mempengaruhi ukuran partikel sehingga secara tidak langsung mempengaruhi ukuran kristalnya. Untuk beberapa aplikasi ukuran nanopartikel penting untuk dikontrol. Bentuk nanostruktur seng oksida dapat dikontrol dengan memvariasikan konsentrasi prekursor $\mathrm{ZnO}$ pada saat sintesis (Kurda dkk., 2015). Diameter nanorod seng oksida yang disintesis dari larutan prekursor zinc nitrate tetrahydrate $\left(\mathrm{Zn}\left(\mathrm{NO}_{3}\right)_{2} \cdot 4 \mathrm{H}_{2} \mathrm{O}\right)$ dan hexamethylenetetramine $\left(\mathrm{C}_{6} \mathrm{H}_{12} \mathrm{~N}_{4}\right)$ menggunakan metode hidrotermal dengan variasi konsentrasi larutan 15, 20 25, 30, dan $35 \mathrm{mM}$ bertambah dengan kelajuan 34,4 nm/mM (Kurda dkk., 2015). Pada penelitian Kurda dkk. (2015) pembentukan nanopartikel seng oksida dilakukan pada substrat kaca yang dilapisi dengan larutan zinc acetate dehydrate $\left(\mathrm{Zn}\left(\mathrm{CH}_{3} \mathrm{COO}\right)_{2}\right)$ dan ethanol sehingga nanopartikel yang terbentuk berupa film tipis. Pada penelitian tersebut terlihat bahwa konsentrasi prekursor mempengaruhi struktur dan ukuran partikel seng oksida, namun belum dilakukan pengukuran ukuran kristal dari nanorod seng oksida yang terbentuk.

Berdasarkan penjabaran di atas akan diteliti lebih lanjut mengenai dampak variasi konsentrasi prekursor terhadap morfologi dan ukuran kristal nanopartikel seng oksida yang disintesis menggunakan metode hidrotermal. Sintesis nanopartikel oksida dilakukan dengan menggunakan prekursor zinc nitrate tetrahydrate $\left(\mathrm{Zn}\left(\mathrm{NO}_{3}\right)_{2} \cdot 4 \mathrm{H}_{2} \mathrm{O}\right)$ dan hexamethlyenetetramine $\left(\mathrm{C}_{6} \mathrm{H}_{12} \mathrm{~N}_{4}\right)$ dengan pelarut aquades.

\section{METODE}

\subsection{Alat dan Bahan}

Alat yang digunakan untuk pembuatan nanopartikel $\mathrm{ZnO}$ yaitu gelas ukur, spatula, timbangan digital, magnetic stirrer, oven, furnace, autoclave, X-Ray Diffraction, dan Scanning Electron Microscopy. Bahan yang digunakan adalah aquades, Hexamethylenetetramine $\left(\mathrm{C}_{6} \mathrm{H}_{12} \mathrm{~N}_{4}\right)$, dan Zinc nitrate tetrahydrate $\left(\mathrm{Zn}\left(\mathrm{NO}_{3}\right)_{2} \cdot 4 \mathrm{H}_{2} \mathrm{O}\right)$.

\subsection{Teknik Penelitian}

\subsubsection{Sintesis Nanopartikel $\mathrm{ZnO}$}

Sintesis nanopartikel seng oksida akan dilakukan dengan menggunakan metode hidrotermal. zinc nitrate tetrahydrate $\left(\mathrm{Zn}\left(\mathrm{NO}_{3}\right)_{2} \cdot 4 \mathrm{H}_{2} \mathrm{O}\right)$ dan hexamethylenetetramine $\left(\mathrm{C}_{6} \mathrm{H}_{12} \mathrm{~N}_{4}\right)$ digunakan sebagai prekursor. Hexamethylenetetramine dan serbuk zinc nitrate tetrahydrate 
dilarutkan dengan pelarut aquades untuk menghasilkan larutan prekursor dengan konsentrasi 15 $\mathrm{mM}, 20 \mathrm{mM}, 25 \mathrm{mM}, 30 \mathrm{mM}$, dan $35 \mathrm{mM}$. Detail dari komposisi larutan prekursor dengan volume pelarut $50 \mathrm{~mL}$ ditampilkan pada Tabel 1 .

Tabel 1 Massa prekursor untuk setiap konsentrasi

\begin{tabular}{ccc}
\hline $\begin{array}{c}\text { Konsentrasi Larutan } \\
\text { Prekursor }(\mathbf{m M})\end{array}$ & $\begin{array}{c}\text { Zinc Nitrate } \\
\text { Tetrahydrate }(\mathbf{g})\end{array}$ & $\begin{array}{c}\text { Hexamethylenetetramine } \\
(\mathbf{g})\end{array}$ \\
\hline 15 & 0.20 & 0.11 \\
20 & 0.26 & 0.14 \\
25 & 0.33 & 0.18 \\
30 & 0.39 & 0.21 \\
35 & 0.46 & 0.25 \\
\hline
\end{tabular}

Kemudian larutan diaduk menggunakan magnetic stirrer selama satu jam. Larutan yang telah terbentuk diletakkan dalam teflon kemudian dimasukkan ke dalam autoclave dan dipanaskan pada temperatur $95{ }^{\circ} \mathrm{C}$ selama $10 \mathrm{jam}$. Endapan akan terbentuk melalui persamaan reaksi kimia berikut:

$$
\begin{aligned}
& \mathrm{Zn}\left(\mathrm{NO}_{3}\right)_{2}(a q)+\mathrm{C}_{6} \mathrm{H}_{12} \mathrm{~N}_{4}(a q) \rightarrow\left[\mathrm{Zn}\left(\mathrm{C}_{6} \mathrm{H}_{12} \mathrm{~N}_{4}\right)\right]^{2+}(a q)+2 \mathrm{NO}_{3}^{-}(a q) \\
& \mathrm{C}_{6} \mathrm{H}_{12} \mathrm{~N}_{4}+4 \mathrm{H}_{2} \mathrm{O} \leftrightarrow \mathrm{C}_{6} \mathrm{H}_{12} \mathrm{~N}_{4} \mathrm{H}_{4}^{+}+4 \mathrm{OH}^{-} \\
& \left.\left[\mathrm{Zn}\left(\mathrm{C}_{6} \mathrm{H}_{12} \mathrm{~N}_{4}\right)\right]_{2}\right]^{+}(a q)+4 \mathrm{OH}^{-}(a q) \rightarrow \mathrm{Zn}(\mathrm{OH})_{4}^{2-}(a q)+\mathrm{C}_{6} \mathrm{H}_{12} \mathrm{~N}_{4} \\
& \mathrm{Zn}(\mathrm{OH})_{4}^{2-}(a q) \rightarrow \mathrm{Zn}(\mathrm{OH})(s)+2 \mathrm{OH}^{-}(a q) \\
& \mathrm{Zn}(\mathrm{OH})_{2}(s) \rightarrow \mathrm{ZnO}(s)+\mathrm{H} 2 \mathrm{O}
\end{aligned}
$$

Selanjutnya sampel didinginkan pada temperatur ruang. Setelah pendinginan selesai, akan terbentuk serbuk putih. Serbuk putih tersebut kemudian dikeringkan menggunakan furnace dengan suhu $600{ }^{\circ} \mathrm{C}$ selama empat jam.

\subsubsection{Karakterisasi $\mathrm{ZnO}$}

Kemurnian nanoparikel seng oksida yang terbentuk akan dikarakterisasi menggunakan XRD di laboratorium Fisika Universitas Negeri Padang. Data XRD berupa difraktogram akan dianalisis dan dibandingkan dengan data pola difraksi ICDD (International Center for Diffraction Database) dalam Powder Diffraction File (PDF). Ukuran kristal dari sampel seng oksida akan dihitung dari difraktogram dengan menggunakan Persamaan 6.

$$
D=\frac{k \lambda}{B \cos \theta}
$$

dimana $D$ adalah ukuran kristal, $K$ adalah nilai konstanta bentuk partikel $(0,9), \lambda$ adalah panjang gelombang radiasi sinar-x, $B$ adalah lebar penuh garis difraksi pada saat intensitas setengah maksimum, dan $\theta$ adalah sudut Bragg.

Morfologi dari sampel seng oksida yang terbentuk akan dikarakterisasi menggunakan SEM di Laboratorium Scanning Electron Microscopy, Jurusan Fisika, Institut Teknologi Bandung. Hasil gambar yang diperoleh dari pengamatan SEM menunjukkan morfologi permukaan dari sampel seng oksida.

\section{HASIL DAN DISKUSI}

\subsection{Morfologi Nanopartikel $\mathrm{ZnO}$}

Pengaruh konsentrasi larutan prekursor terhadap morfologi nanopartikel $\mathrm{ZnO}$ yang terbentuk dikarakterisasi menggunakan SEM dengan perbesaran $40000 \mathrm{x}$. 

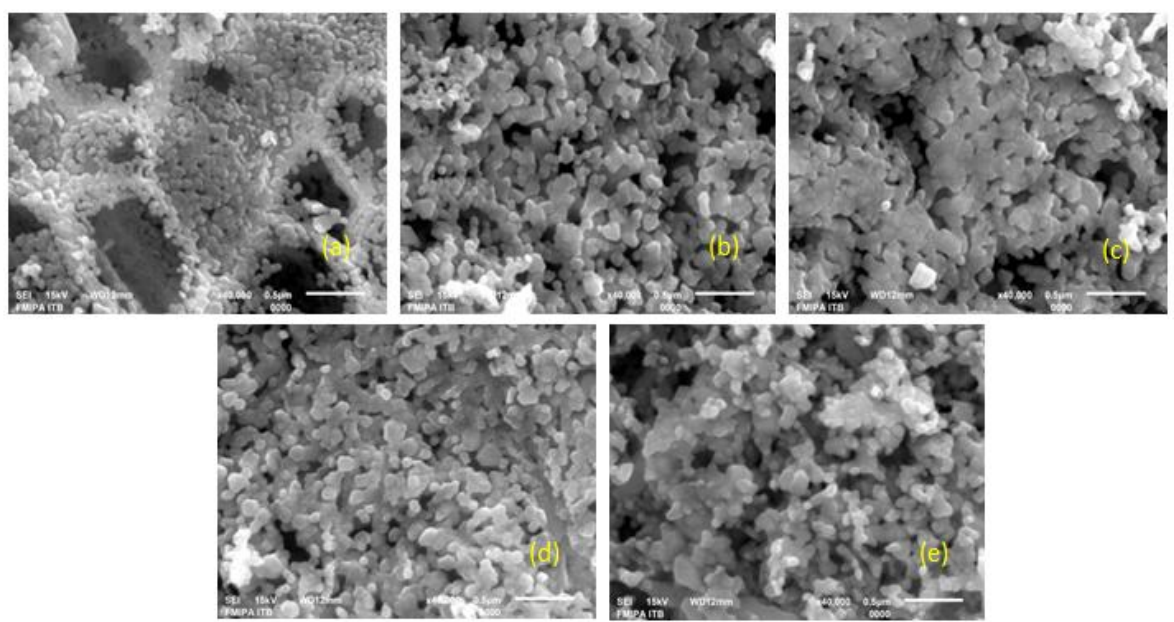

Gambar 1 Citra SEM nanopartikel $\mathrm{ZnO}$ yang disintesis dengan metode hidrotermal konsentrasi (a) $15 \mathrm{mM}$, (b) $20 \mathrm{mM}$, (c) $25 \mathrm{mM}$, (d) $30 \mathrm{mM}$, dan (e) $35 \mathrm{mM}$

Berdasarkan hasil karakterisasi SEM diperoleh bahwa kelima sampel adalah nanopartikel $\mathrm{ZnO}$ dan terdapat penggumpalan (aglomerasi). Aglomerasi nanopartikel paling dominan terdapat pada sampel $\mathrm{ZnO}$ dengan konsentrasi larutan prekursor $25 \mathrm{mM}$ (Gambar 1 (c)). Aglomerasi dengan meningkatnya konsentrasi larutan prekursor dapat terjadi akibat penggumpalan saat sampel mengendap ketika didinginkan pada temperatur ruang. Aglomerasi menyebabkan ukuran partikel dari sampel tidak seragam.

\subsection{Struktur Kristal Nanopartikel ZnO}

Struktur dan ukuran kristal dari nanopartikel $\mathrm{ZnO}$ dapat diketahui menggunakan XRD. Gambar 2. adalah difraktogram XRD yang menampilkan puncak-puncak difraksi dari sampel. Pola difraksi dari sampel dibandingkan dengan pola difraksi standar yang dikeluarkan oleh International Center for Diffraction Database (ICDD).

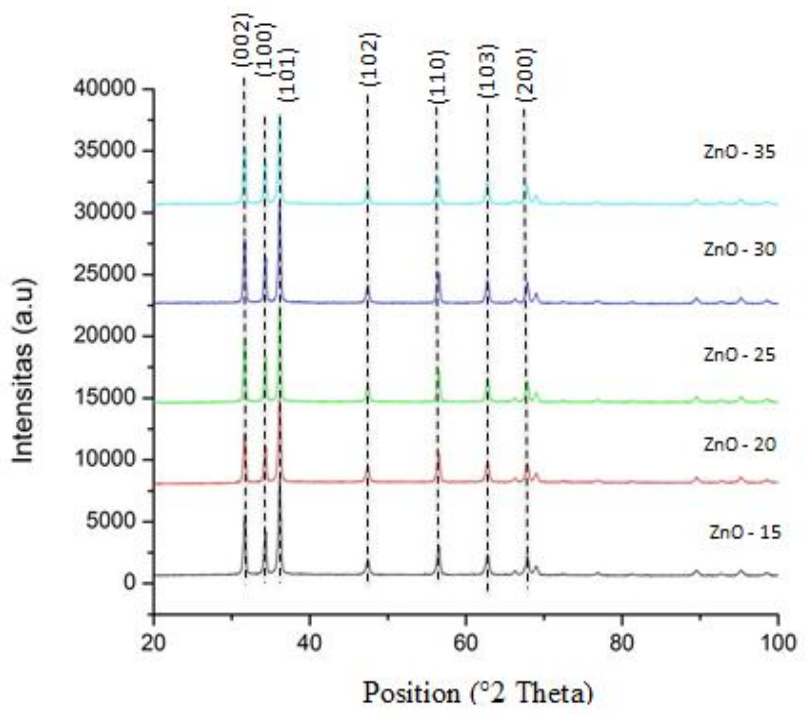

Gambar 2 Pola difraksi sinar-X nanopartikel $\mathrm{ZnO}$ dengan konsentrasi larutan prekursor 15 $\mathrm{mM}, 20 \mathrm{~m}, 25 \mathrm{mM}, 30 \mathrm{mM}$, dan $35 \mathrm{mM}$

Puncak tertinggi berada pada posisi $2 \theta=36,14^{\circ}$ setiap sampel, posisi puncak setiap sampel mengalami pergeseran sekitar $0,01^{\circ}$. Indeks Miller puncak tertinggi setiap sampel sama yaitu (101). Dapat dilihat pada Gambar 2. ZnO yang disintesis pada konsentrasi $30 \mathrm{mM}$ memiliki puncak yang lebih tinggi daripada sampel lainnya. Hal ini menandakan bahwa tingkat kristalinitas paling tinggi berada pada sampel dengan konsentrasi larutan prekursor $30 \mathrm{mM}$. 
Tabel 2 Perbandingan parameter kristal $\mathrm{ZnO}$ untuk setiap sampel

\begin{tabular}{lllllllll}
\hline Sampel & $\boldsymbol{2 \theta}\left(^{\circ}\right)$ & $\begin{array}{c}\text { Sistem } \\
\text { kristal }\end{array}$ & $\boldsymbol{\alpha}$ & $\boldsymbol{\beta}$ & $\boldsymbol{\gamma}$ & $\boldsymbol{a}(\mathbf{\AA})$ & $\boldsymbol{b}(\mathbf{\AA})$ & $\boldsymbol{c}(\AA)$ \\
\hline ZnO 15 & 36,1479 & heksagonal & $90^{\circ}$ & $90^{\circ}$ & $120^{\circ}$ & 3,2568 & 3,2568 & 5,2125 \\
$\mathrm{ZnO} 20$ & 36,1398 & heksagonal & $90^{\circ}$ & $90^{\circ}$ & $120^{\circ}$ & 3,2568 & 3,2568 & 5,2125 \\
$\mathrm{ZnO} 25$ & 36,1482 & heksagonal & $90^{\circ}$ & $90^{\circ}$ & $120^{\circ}$ & 3,2535 & 3,2535 & 5,2151 \\
$\mathrm{ZnO} 30$ & 36,1381 & heksagonal & $90^{\circ}$ & $90^{\circ}$ & $120^{\circ}$ & 3,2568 & 3,2568 & 5,2125 \\
$\mathrm{ZnO} 35$ & 36,1338 & heksagonal & $90^{\circ}$ & $90^{\circ}$ & $120^{\circ}$ & 3,2568 & 3,2568 & 5,2125 \\
\hline
\end{tabular}

Tabel 2 menunjukkan perbandingan parameter kristal $\mathrm{ZnO}$ untuk setiap sampel. Sistem kristal yang terbentuk pada masing-masing sampel adalah heksagonal dengan parameter kisi $\alpha=$ $\beta=90^{\circ}$ dan $\gamma=120^{\circ}$ sedangkan nilai $a, b$, dan $c$ pada masing-masing sampel sama untuk konsentrasi 15, 20,30, dan $35 \mathrm{mM}$. sedangkan pada sampel $25 \mathrm{mM}$ nilai $a$ dan $b$ berbeda dari sampel lain yaitu 3,2535 $\AA$ dan nilai c 5,2151 A. Perbedaan nilai konstanta kisi pada sampel dengan konsentrasi larutan prekursor $25 \mathrm{mM}$ disebabkan oleh aglomerasi yang mengakibatkan adanya perubahan nilai parameter kisi tanpa mempengaruhi struktur kristal yang terbentuk. Dapat dilihat pada Tabel 4.1 struktur kristal pada setiap sampel berbentuk wurtzite dengan konstanta kisi $a=b=3,2 \AA$ dan $c=5,2 \AA$. Berdasarkan hasil karakterisasi XRD tidak ditemukan adanya senyawa lain yang terbentuk akibat dari variasi konsentrasi.

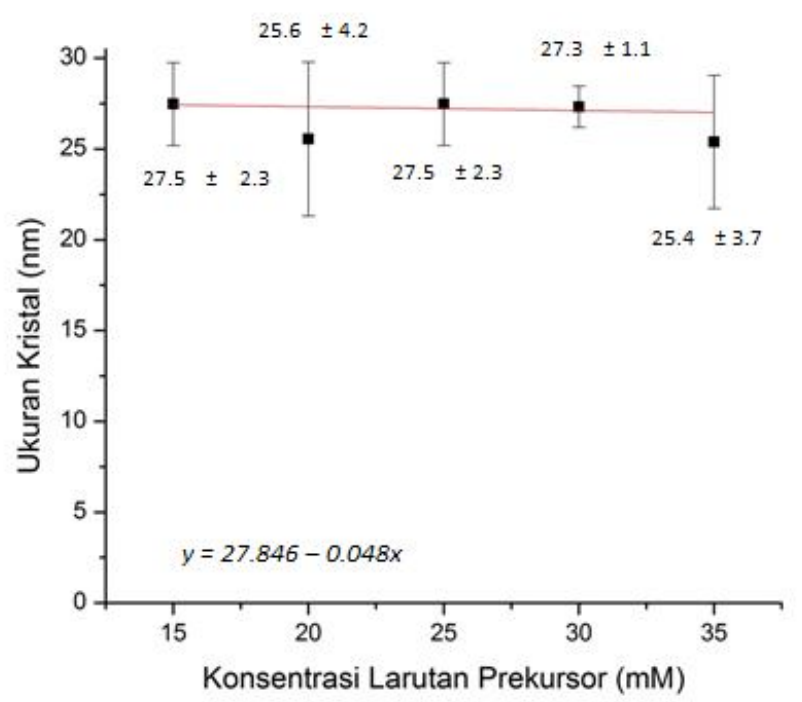

Gambar 3 Grafik pengaruh konsentrasi larutan prekursor terhadap ukuran kristal nanopartikel $\mathrm{ZnO}$ yang terbentuk

Gambar 3. merupakan grafik pengaruh konsentrasi larutan prekursor terhadap ukuran kristal nanopartikel $\mathrm{ZnO}$ yang terbentuk. Ukuran kristal dengan konsentrasi larutan prekursor 15 $\mathrm{mM}$ adalah 27,5 $\pm 2,3 \mathrm{~nm}$. Kemudian ukuran kristal mengalami penurunan menjadi 25,6 44,2 $\mathrm{nm}$. Ukuran kristal kembali meningkat pada partikel $\mathrm{ZnO}$ dengan konsentrasi larutan prekursor $25 \mathrm{mM}$ yaitu $27,5 \pm 2,3 \mathrm{~nm}$. Pada partikel $\mathrm{ZnO}$ dengan konsentrasi larutan prekursor $30 \mathrm{mM}$ dan $35 \mathrm{mM}$ ukuran kristal mengalami penurunan dibandingkan dengan ukuran kristal pada konsentrasi $25 \mathrm{mM}$ yaitu 27,3 $\pm 1,1 \mathrm{~nm}$ dan $25,4 \pm 3,7 \mathrm{~nm}$. Dapat dilihat pada Gambar 4.5 ZnO dengan konsentrasi 15, 25, dan $30 \mathrm{mM}$ memiliki ukuran kristal yang hampir sama. Sedangkan pada sampel dengan konsentrasi $20 \mathrm{mM}$ dan $35 \mathrm{mM}$ memiliki diamater kristal yang hampir sama namun sedikit lebih kecil dibandingkan ketiga sampel lainnya. Secara umum, dapat disimpulkan bahwa variasi konsentrasi larutan prekursor mempengaruhi ukuran kristal dari nanopartikel $\mathrm{ZnO}$ yang terbentuk akan tetapi perubahan yang terjadi tidak signifikan. 


\section{KESIMPULAN}

Konsentrasi larutan prekursor menyebabkan adanya perubahan ukuran kristal, akan tetapi perubahan yang terjadi tidak terlalu signifikan. Partikel $\mathrm{ZnO}$ yang terbentuk memiliki struktur kristal berbentuk heksagonal dengan ukuran kristal yang tidak terlalu dipengaruhi oleh konsentrasi larutan prekursor.

\section{DAFTAR PUSTAKA}

Abdullah, M., Pengantar Nanosains, Institut Teknologi Bandung (ITB), Bandung, 2009.

Chitira, P. R. dan John, T. T., Influence of Vacum and Annealling on the Visible Luminesensi in ZnO Nanoparticles, Journal of Luminescence, 185, 212-218, 2017.

Ikono, R., Nofrizal, Nugroho, D. W., Rahman, T. P., Widyaningrum, R., Widayanto, W. B., Sukarto, A., Siswanto, dan Rochman, N. T., Sintesis Nanopartikel ZnO dengan Metode Mechano Chemical Milling, Prosiding Pertemuan Ilmiah Ilmu Pengetahuan dan Teknologi Bahan 2012, Serpong, 2012.

Kurda, A. H., Hassan, Y. M., dan Ahmed N. M., Controlling Diameter, Length, and Characterization of ZnO Nanorods by Simple Hydrothermal Method of Solar Cells, World Journal of Nanoscience and Engineering, 5, 34-40, 2015.

Raji R., dan Gopchandran, K. G., ZnO Nanostructures with Tunable Visible Luminesensi: Effects of Kinetics of Chemical Reduction and Annealing. Journal of Science: Advance Materials and Devices, 2, 51-58, 2017.

Saragi, T., Purba, Y. R., Dhiya, S. A., Oktaviani, M., Risdiana, dan Bahtiar, A., Kontrol Ukuran Kristal Nanopartikel $\mathrm{ZnO}$ yang Disintesis dengan Metode Hidrotermal, Prosiding Pertemuan Ilmiah XXIX Jateng \& DIY, Yogyakarta, 2015.

Witjaksono, A., Karakterisasi Nanokristalin ZnO Hasil Presipitasi dengan Perlakuan Pengeringan, Anil dan Pasca-Hidrotermal, Tesis, Departemen Metalurgi dan Material Universitas Indonesia, Depok, 2011. 